\title{
Taxifolin ameliorates cerebral ischemia-reperfusion injury in rats through its anti-oxidative effect and modulation of NF-kappa B activation
}

\author{
Yea-Hwey Wang ${ }^{1}$, Wen-Yen Wang ${ }^{2}$, Chia-Che Chang ${ }^{5}$, Kuo-Tong Liou ${ }^{6}$, \\ Yen-Jen Sung ${ }^{4}$, Jyh-Fei Liao ${ }^{1}$, Chieh-Fu Chen ${ }^{1}$, Shiou Chang ${ }^{2}$, Yu-Chang Hou ${ }^{2}$, \\ Yueh-Ching Chou ${ }^{7,8} \&$ Yuh-Chiang Shen ${ }^{3,5, *}$ \\ ${ }^{1}$ Institute of Pharmacology, National Yang-Ming University, Taipei, Taiwan; ${ }^{2}$ Departments of Surgery and \\ Chinese Medicine, Tao-yuan and Hsin-chu General Hospitals, Department of Health, Taipei, Taiwan; \\ ${ }^{3}$ National Research Institute of Chinese Medicine, Taipei, Taiwan; ${ }^{4}$ Anatomy and Cell Biology, School of \\ Medicine, National Yang-Ming University, Taipei, Taiwan; ${ }^{5}$ Institute of Biomedical Sciences, National \\ Chung-Hsing University, Taichung, Taiwan; ${ }^{6}$ Department of Chinese Martial Arts, Chinese Culture \\ University, Taipei, Taiwan; ${ }^{7}$ Department of Pharmacy, Veterans General Hospital, Taipei, Taiwan; ${ }^{8}$ School \\ of Pharmacy, Taipei Medical University, Taipei, Taiwan
}

Received 20 June 2005; accepted 8 September 2005

(c) 2005 National Science Council, Taipei

Key words: cerebral ischemic-reperfusion, COX-2, ICAM-1 (CD54), iNOS, Mac-1 (CD11b/CD18), nuclear factor kappa B (NF- $\kappa \mathrm{B})$, reactive oxygen species, taxifolin

\section{Summary}

Infarction in adult rat brain was induced by middle cerebral arterial occlusion (MCAO) followed by reperfusion to examine whether taxifolin could reduce cerebral ischemic reperfusion $(\mathrm{CI} / \mathrm{R})$ injury. Taxifolin administration ( 0.1 and $1.0 \mu \mathrm{g} / \mathrm{kg}$, i.v.) $60 \mathrm{~min}$ after MCAO ameliorated infarction (by $42 \% \pm 7 \%$ and $62 \% \pm 6 \%$, respectively), which was accompanied by a dramatic reduction in malondialdehyde and nitrotyrosine adduct formation, two markers for oxidative tissue damage. Overproduction of reactive oxygen species (ROS) and nitric oxide (NO) via oxidative enzymes (e.g., COX-2 and iNOS) was responsible for this oxidative damage. Taxifolin inhibited leukocyte infiltration, and COX-2 and iNOS expressions in CI/R-injured brain. Taxifolin also prevented Mac-1 and ICAM-1 expression, two key counter-receptors involved in firm adhesion/transmigration of leukocytes to the endothelium, which partially accounted for the limited leukocyte infiltration. ROS, generated by leukocytes and microglial cells, activated nuclear factor-kappa $\mathrm{B}(\mathrm{NF}-\kappa \mathrm{B})$ that in turn signaled up-regulation of inflammatory proteins. $\mathrm{NF}-\kappa \mathrm{B}$ activity in $\mathrm{CI} / \mathrm{R}$ was enhanced 2.5 -fold over that of sham group and was inhibited by taxifolin. Production of both ROS and NO by leukocytes and microglial cells was significantly antagonized by taxifolin. These data suggest that amelioration of $\mathrm{CI} / \mathrm{R}$ injury by taxifolin may be attributed to its antioxidative effect, which in turn modulates NF- $\kappa \mathrm{B}$ activation that mediates $\mathrm{CI} / \mathrm{R}$ injury.

\section{Introduction}

Acute ischemic stroke is commonly disabling and also an important cause of death in industrialized

*To whom correspondence should be addressed. Tel: 886-2-2820 1999 ext. 9101; Fax: 886-2-28264266, E-mail: yuhcs@nricm.edu.tw Present address: Yea-Hwey Wang, Wen-Yen Wang, Chia-Che Chang, and Kuo-Tong Liou contributed equally to this work. countries with a high incidence affecting up to $0.2 \%$ of the population each year [1]. Ischemic strokeinduced brain injury is closely correlated with oxidative/nitrosative damage induced by overproduction of reactive oxygen species (ROS) [e.g., hydroxyl radicals $\left(\mathrm{OH}^{-}\right)$, superoxide anions $\left(\mathrm{O}_{2}^{-}\right)$, and hydrogen peroxide $\left.\left(\mathrm{H}_{2} \mathrm{O}_{2}\right)\right]$ and reactive nitrogen species (RNS) [e.g., nitric oxide (NO) and 
peroxynitrite $\left.\left(\mathrm{OONO}^{-}\right)\right]$in response to activation of inflammatory mediators produced by recruited leukocytes (e.g., neutrophils), active microglia cells, and/or neurons and astrocytes in injured tissue [24].

Although pathologic mechanisms leading to cerebral ischemic/reperfusion $(\mathrm{CI} / \mathrm{R})$ injury are complicated, it has been emphasized that multiple fundamental cell injury mechanisms are involved, including excitotoxicity, overproduction of ROS/ RNS, inflammation, and apoptosis [5-7]. After the onset of ischemia, energy deficits lead to ionic disruption and mitochondrial dysfunction that serve as activators for free radical producingenzyme systems including mitochondria, cyclooxygenase (COX), xanthine oxidase, NADPH oxidase, and neuronal- or inducible-nitric oxide synthase (nNOS or iNOS) which overproduce ROS and RNS. ROS and RNS damage tissue by attacking DNA or inducing lipid peroxidation or protein nitrosylation of the cell membrane and organelles [6]. In tissue damaged by ROS/RNS, an inflammatory cascade is initiated leading to complement activation (e.g. C5a), firm adhesion molecule upregulation (e.g., ICAM-1 and Mac-1), leukocyte infiltration, activation/expression of NOS and COX, and release of cytokines (e.g., IL- $1 \beta$ and TNF- $\alpha$ ) which amplify inflammation [8]. Many reports have indicated that activation of nuclear factor-kappa B (NF- $\kappa$ B) plays a pivotal role in mediating oxidative stress-induced cell injury and in the regulation of post-ischemic inflammation, possibly through upregulation of inflammatory genes/proteins that contribute to cell death in cerebral ischemia [9-11]. Multiple pathological mechanisms as mentioned above are involved in $\mathrm{CI} / \mathrm{R}$-induced tissue injury, and the fact that many drugs work in animals but fail in humans [5] suggests that combination therapies or drug(s) that can target multiple sites of these mechanisms can provide the potential to meet the treatment challenges of ischemic stroke.

Flavonoids structurally similar to quercetin have been reported to exhibit multiple pharmacological effects and display beneficial actions against cardiovascular diseases [12-13] but their potential for CNS protection and the exact mechanisms of action remain unclear. In addition, taxifolin (dihydroquercetin, Figure 1) has been shown to exhibit anti-inflammatory effects and protect against oxidative cellular injury in rat peritoneal macrophages [14] and human endothelial cells [15], possibly by inhibiting the expression of intercellular adhesion molecule-1 (ICAM-1) [16] and Mac-1 $(\mathrm{CD} 11 \mathrm{~b} / \mathrm{CD} 18)$, a dominant $\beta 2$ integrin in activated neutrophils [17]. Expression of ICAM-1 on inflammatory target cells (e.g., endothelial cells) mediates activation and firm adhesion of circulating neutrophils to injured tissue through interaction with $\beta 2$ integrin expressed on neutrophils [18]. Drugs with anti-oxidative or anti-inflammatory effects can possibly modulate the upregulation of Mac-1 [19]. These observations suggest that impairment of interactions between peripheral neutrophils and their target cells might prevent further activation of these inflammatory cells to infiltrate injured tissue (e.g., the brain) and confer on drugs potential benefits for the prevention or treatment of cardiovascular disorders, e.g., stroke.

In our previous study, we reported that taxifolin exhibits an inhibitory effect on surface Mac-1 expression and Mac-1-dependent firm adhesion by human neutrophils, as well as the possible mechanism(s) underlying its anti-inflammatory effect [17]. In this current work we set up an animal model of ischemic stroke to elucidate whether taxifolin, with anti-inflammatory potential, can protect animals from $\mathrm{CI} / \mathrm{R}$ injury. In particular, some key molecular mechanisms involved in the oxidative/nitrosative damage by $\mathrm{CI} / \mathrm{R}$ injury and the possible targets of taxifolin were elucidated in in vivo and in vitro systems.

\section{Materials and methods}

\section{Animals and induction of cerebral ischemic-reperfusion injury}

All animal procedures and protocols were performed in accordance with the Guide For The Care and Use of Laboratory Animals (NIH publication, 85-23, revised 1996) and were reviewed and approved by the Animal Research Committee in our institute. Male adult LongEvans rats (National Laboratory Animal Breeding and Research Center, Taipei, Taiwan) (250-350 g) were used. Rats were anesthetized with chloral hydrate $(300 \mathrm{mg} / \mathrm{kg}$, i.p.). The right femoral artery was cannulated for continuous monitoring of the heart rate and blood pressure. The right middle cerebral artery (RMCA) was ligated. Immediately 
<smiles>O=C1c2c(O)cc(O)cc2OC(c2ccc(O)c(O)c2)C1O</smiles>
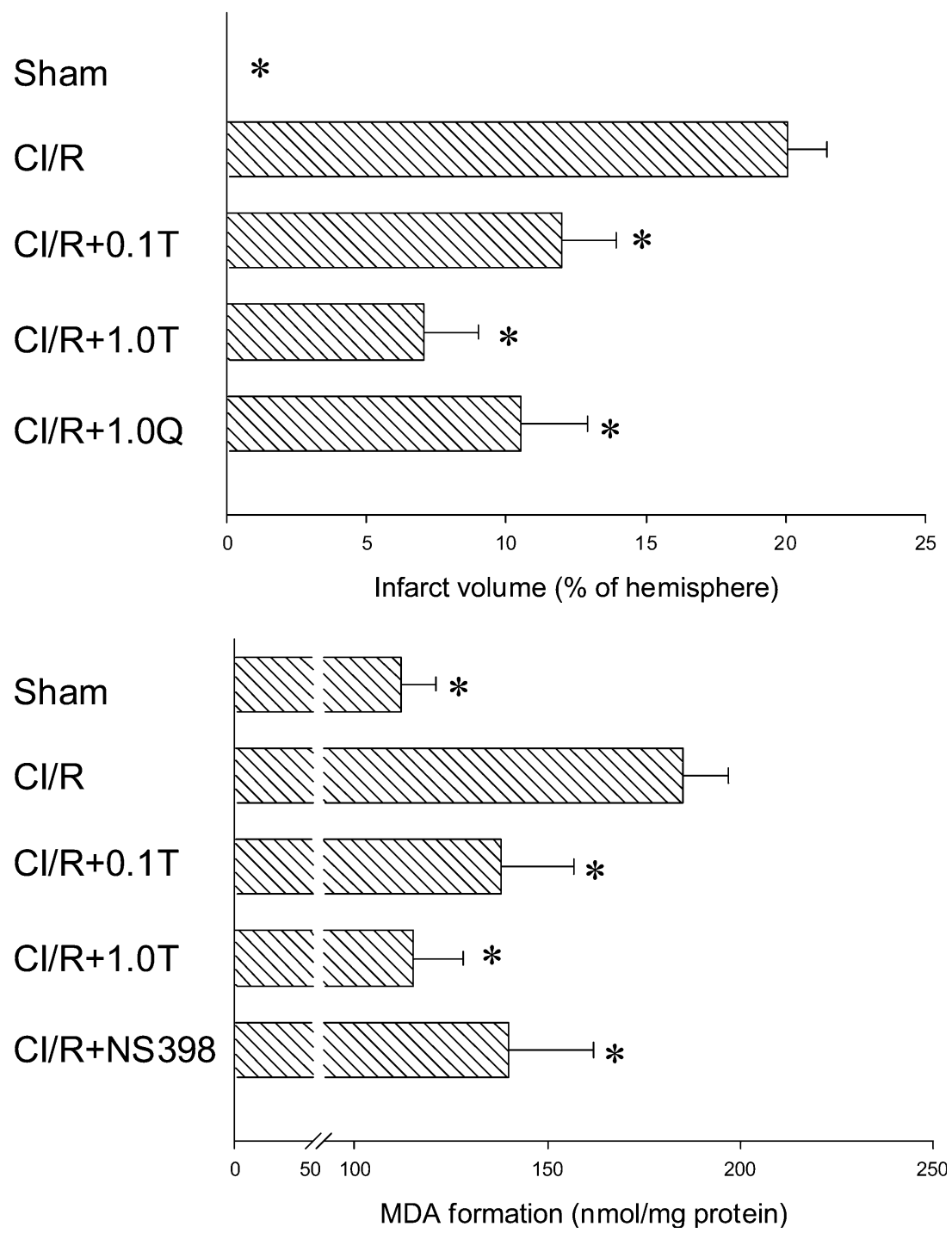

Figure 1. Effect of taxifolin on $\mathrm{CI} / \mathrm{R}$-induced cerebral infarction and lipid peroxidation in the rats. Whole brains from shamoperated rats (sham) or $\mathrm{CI} / \mathrm{R}$-injured rats receiving vehicle control $(\mathrm{CI} / \mathrm{R}), 0.1$ or $1.0 \mu \mathrm{g} / \mathrm{kg}$ (i.v.) taxifolin $(\mathrm{CI} / \mathrm{R}+0.1 \mathrm{~T}$ or $\mathrm{CI} /$ $\mathrm{R}+1.0 \mathrm{~T}), 1.0 \mu \mathrm{g} / \mathrm{kg}$ (i.v.) quercetin $(\mathrm{CI} / \mathrm{R}+1.0 \mathrm{Q})$, or $1 \mu \mathrm{g} / \mathrm{kg} \mathrm{NS} 398(\mathrm{CI} / \mathrm{R}+\mathrm{NS} 398)$ were removed for the determination of infarct volume by TTC staining (upper panel) or lipid peroxidation by MDA formation (lower panel). Data were calculated as the percent of infarct volume of the right hemisphere brain (cerebral infarction) or $\mathrm{nmol} / \mathrm{mg}$ protein (MDA formation), and are expressed as the mean $\pm \operatorname{SEM}\left(n=10\right.$ for each data point). ${ }^{*} p<0.05$ as compared with the $\mathrm{CI} / \mathrm{R}$ group by one-way ANOVA followed by Dunnett's test. The inset (top) shows the chemical structure of taxifolin. 
after occlusion of the RMCA, both common carotid arteries (CCAs) were clipped for $1 \mathrm{~h}$ to produce cortical infarction. Twenty-four hours after the surgery, the rats were anesthetized and sacrificed. During the entire experiment, the blood gas data and physiological data were monitored as in our previous report [20]. The experimental grouping included one sham-operated group (sham, $n=10)$, two $(0.1$ and $1.0 \mu \mathrm{g} / \mathrm{kg})$ taxifolintreated groups ( $n=10$, for each dose), and one CI/ $\mathrm{R}$ group $(\mathrm{CI} / \mathrm{R}$ only, $n=10)$. Sham-operated rats underwent the same surgical procedures without RMCA occlusion or CCA clipping. Additional animals from the groups described above were used for other assays (leukocyte infiltration, lipid peroxidation, immuno-blotting, and semiquantitative RT-PCT).

\section{Drug administration}

Drug solutions $(0.3 \mathrm{ml})$ were administered intravenously (i.v.) via the right femoral vein $60 \mathrm{~min}$ after RMCAO at two different doses ( 0.1 or $1.0 \mu \mathrm{g} / \mathrm{kg}$ ). Taxifolin (Sigma-Aldrich, USA) was first dissolved in $10 \mu \mathrm{l}$ of ethanol and further suspended in normal saline to make a clear stock solution of $1.0 \mathrm{mg} / \mathrm{ml}$, then this was diluted with normal saline to the desired concentrations. The final concentration of ethanol in the injected taxifolin solution was less than $0.001 \%(\mathrm{v} / \mathrm{v})$. Rats injected with $0.3 \mathrm{ml}$ of normal saline containing $0.001 \%(\mathrm{v} / \mathrm{v})$ ethanol were used as vehicle control in $\mathrm{CI} / \mathrm{R}$ only and sham-operated groups.

\section{Evaluation of infarct volume}

Twenty-four hours after reperfusion, rats were sacrificed by rapid decapitation under deep anesthesia. Whole brains were rapidly removed. Immediately after being weighed, the brain was sliced into 2-mm-thick coronal sections and stained with 2\% 2,3,5-triphenyltetrazoliumchloride (TTC, Sigma-Aldrich) for $30 \mathrm{~min}$ at $37^{\circ} \mathrm{C}$ in the dark, followed by fixation with $10 \%$ of formalin at room temperature overnight. Brain slices lacking red staining defined the infarct area. The slices were recorded by digital photography and analyzed by an image processing system (AIS software, Imaging Research, Brock Univ., Ontario, Canada). Infarct volume was obtained according to the indirect method proposed by Swanson et al. [21] and corrected for edema by comparing the volume of ischemic and nonischemic hemispheres as described [22]. The infarct volume was expressed as a percentage of the hemispheric volume $(\%$ of hemisphere).

\section{Measurement of leukocyte infiltration}

Myeloperoxidase (MPO) activity is used to quantitatively assess leukocyte infiltration into ischemic tissue [23]. Briefly, brain tissues were homogenized in $1.5 \mathrm{ml}$ of potassium phosphate buffer (PPB, $50 \mathrm{mM}, \mathrm{pH}$ 6). One milliliter of the homogenate was pelleted and suspended in PPB containing $0.5 \%$ hexadecyltrimethylammonium bromide. After three cycles of freezing and thawing, sample was sonicated on ice for $10 \mathrm{~s}$, and centrifuged at $12,000 \times g$ for $10 \mathrm{~min}$. MPO activity was determined in the supernatants by mixing supernatant with PPB containing $o$-dianisidine chloride and hydrogen peroxide $\left(\mathrm{H}_{2} \mathrm{O}_{2}\right)$. The absorbance at a wavelength of $460 \mathrm{~nm}\left(\mathrm{OD}_{460}\right)$ was determined by spectrophotometry over $2 \mathrm{~min}$ and normalized using protein concentration. Values of the tissue MPO activity (infiltration index) are expressed as $\mathrm{OD}_{460} \times 100 / \mathrm{mg}$ protein. The protein concentration was determined with a commercial kit (BioRad Laboratory, USA).

\section{Measurement of lipid peroxidation}

Lipid peroxidation of the frozen cerebral cortex was determined by the tissue malondialdehyde (MDA) level as measured by the formation of thiobarbituric acid (TBA)-reactive substances (TBARSs) [24]. Briefly, brain tissues were homogenized with $10 \times(\mathrm{w} / \mathrm{v})$ of cold $1.5 \% \mathrm{KCl}$. The homogenate was mixed with a $1 \%$ phosphoric acid and $6 \%$ TBA (Sigma-Aldrich) aqueous solution. The mixture was heated for $45 \mathrm{~min}$ in a boiling water bath. After cooling, n-butanol was added and mixed vigorously. The absorbance of the butanol phase was measured at $525 \mathrm{~nm}$. A serially diluted MDA (Sigma-Aldrich) solution was prepared and used as a standard. Data (MDA) were expressed as $\mathrm{nmol} / \mathrm{mg}$ protein.

\section{Western immunoblot analysis}

Equal amounts of protein were subjected to sodium dodecyl sulfate-polyacrylamide gel 
electrophoresis (SDS-PAGE) and electro-transferred to a hydrophobic polyvinylidene difluoride (PVDF) membrane. After blocking with $5 \%$ nonfat milk in PBS containing $0.05 \%$ Tween 20 (PBST) at $4{ }^{\circ} \mathrm{C}$ for $1 \mathrm{~h}$, the membrane was washed 3 times with PBST and incubated overnight at $4{ }^{\circ} \mathrm{C}$ with an antibody against nitrotyrosine (rabbit-anti-rat, isotype: $\mathrm{IgG}$; Upstate, USA), COX-2 (goat-anti-rat, isotype: IgG; Santa Cruz Biotechnology, USA), iNOS (mouse-anti-rat, isotype: $\mathrm{IgG}$; $\mathrm{BD}$ Bioscience Pharmingen, USA) or ICAM-1 (mouse-anti-rat, isotype: $\mathrm{IgG}$; Serotec, UK) at a proper dilution (1:100 or $1: 1000)$. After additional washes with PBST, the membrane was incubated with a second antibody (anti-rabbit, anti-goat, or anti-mouse, respectively, isotype: $\operatorname{IgG}$ conjugated with horseradish peroxidase; Santa Cruz Biotechnology) for $1 \mathrm{~h}$ at room temperature. The immunoblot on the membrane was visible after developing with an enhanced chemiluminescence (ECL) system (Perkin-Elmer).

\section{Semiquantitative revers-transcriptase-polymerase chain reaction ( $R T-P C R$ )}

Total RNA was prepared from frozen cerebral cortex using a NucleoSpin RNA II kit (BD Biosciences Clontech). RNA (300 ng) was used to perform RT-PCR with Titanium One-step RTPCR kit (BD Biosciences Clontech). Primers used were specific for COX-2 (upstream: 5'-ACA CTC TAT CAC TGG CAT CC-3', downstream: 5'GAA GGG ACA CCC TTT CAC AT-3'; expected PCR product size: $584 \mathrm{bp}$ ), iNOS (upstream: 5'-CCA ACA ACA CAG GAT GACC-3', downstream: 5'-CCT GAT GTT GCC ACT GTT AG-3'; expected PCR product size: $602 \mathrm{bp}$ ), and ICAM-1 (upstream: 5'-AGA CAC AAG CAA GAG AAG AA-3', downstream: 5'-GAG AAG CCC AAA CCC GTA TG-3'; expected PCR product size: $233 \mathrm{bp}$ ). Each PCR product was normalized to a housekeeping gene, glyceraldehydes 3-phosphate dehydrogenase (GAPDH; upstream: 5'-CCC TCA AGA TTG TCA GCA ATG C-3', downstream: 5'-GTC CTC AGT GTA GCC CAG GAT-3'; expected PCR product size: $410 \mathrm{bp}$ ). Generally the following condition were used: $94{ }^{\circ} \mathrm{C}$ for $5 \mathrm{~min}$ followed by $25-30$ cycles of $94{ }^{\circ} \mathrm{C}$ for $30 \mathrm{~s}, 58{ }^{\circ} \mathrm{C}$ for $30 \mathrm{~s}, 68{ }^{\circ} \mathrm{C}$ for $1 \mathrm{~min}$. PCR products were electrophoresed and analyzed with a Molecular Imager FX (Bio-Rad,
USA). The data were processed with Quantity One software (Bio-Rad), and RNA levels were calculated as specific RNA-to-GAPDH ratios to determine the relative amounts of the genes of interest.

\section{Neutrophil preparation}

Peripheral whole blood was collected for the neutrophil preparation [25]. The leukocyte-rich (upper) layer was collected and subjected to centrifugation. Neutrophils were separated by a Ficoll gradient centrifugation method followed by lysis of contaminating erythrocytes and washed three times with cold phosphate-buffered saline (PBS). The purified sample, containing more than $95 \%$ neutrophils, was used for the in vitro assay including ROS production and Mac-1 (CD11b/CD18) expression. Cell viability was measured by trypan blue exclusion assay at the end of the experiments.

\section{Measurement of reactive oxygen species (ROS) production by neutrophils}

Production of ROS was evaluated according to our previous report [17]. PMA (phorbol-12myristate-13-acetate)-induced ROS production in neutrophils was determined by luminol-amplified chemiluminescence in the presence or absence of taxifolin. Briefly, taxifolin-pretreated neutrophils were incubated with luminol. Cells were then immediately stimulated with PMA in which chemiluminescence was monitored every $1 \mathrm{~min}$ for $30 \mathrm{~min}$ with a microplate luminometer reader (Orion ${ }^{\circledR}$, Germany), and results are represented as relative light units (RLU). Peak levels were recoded to calculate the activity of the test drugs. Data are expressed as RLU\% of the vehicle control. The $50 \%$ inhibitory concentration $\left(\mathrm{IC}_{50}\right)$ of PMA-triggered chemiluminescence by test drugs was calculated using a semilog-plot transformation of the data.

\section{Measurement of Mac-1 (CD11b/CD18) up-regulation by neutrophils}

Up-regulation of Mac-1 was analyzed as in our previous study [17]. In brief, taxifolin-pretreated cells were stimulated with PMA. Cells were then pelleted and resuspended in PBS containing 10\% FBS and $10 \mathrm{mM}$ sodium azide. Cells were incubated in the dark for $60 \mathrm{~min}$ with a 
proper aliquot of fluorescein isothiocyanate (FITC)-conjugated anti-Mac-1 antibody (mouse anti-rat $\mathrm{CD} 11 \mathrm{~b}$, class $\mathrm{IgG}_{1}$; $\mathrm{BD}$ Biosciences Pharmingen) or a non-specific mouse antibody (class $\mathrm{IgG}_{1}$, Sigma-Aldrich) as a negative control. After two washes with PBS containing 5\% FBS, stained-cells were resuspended in flow cytometric sheath fluid (Becton Dickinson) containing 1\% paraformaldehyde, and Mac-1 expression was analyzed by a flow cytometer (FACSCalibur ${ }^{\mathrm{TM}}$ ). Data were expressed as the mean channel fluorescence for each sample as calculated by the CellQuest ${ }^{\circledR}$ software (Becton Dickinson).

\section{Determination of $N F-\kappa B$ activation}

Frozen cerebral cortex was homogenized and was extracted using a nuclear extraction reagent (Pierce NE-PER; USA). An NF- $\kappa$ B p65 Transcription Factor Assay Kit (Pierce) consisting of a 96-well plate onto which the oligonucleotide duplex containing the NF- $\kappa \mathrm{B}$ consensus site (5'GGGACTTTCC-3') was pre-coated was used to monitor $\mathrm{NF}-\kappa \mathrm{B}$ activation. The active form of $\mathrm{NF}-\kappa \mathrm{B}$ in the nuclear extract specifically binds to this consensus site and is recognized by the primary antibody. A horseradish peroxidaseconjugated secondary antibody provided the chemiluminescent quantification. Results were expressed as relative light units (RLU). TNF$\alpha$-activated HeLa whole-cell extract provided by the manufacturer was used as a positive control for $\mathrm{NF}-\kappa \mathrm{B}$ activity. Wild-type (5'-CACAGTTGAGG GGACTTTCCCAGGC-3') and mutant (5'-CAC AGTTGAGGCCACTTTCCCAGGC-3') NF- $\kappa$ B competitor duplexes were included to contrast the specific binding of $\mathrm{NF}-\kappa \mathrm{B}$.

Cell culture and measurements of nitric oxide (NO) and intracellular reactive oxygen species (ROS) production by microglial cells

The murine microglia cell line, BV2, was generously provided by Dr. Greer M. Murphy, Jr. from the Department of Psychiatry (Stanford University School of Medicine, Stanford, CA). These cells were originally isolated from neonatal mouse brain and immortalized by infection with a v-raf/ v-myc-carrying retrovirus (J2) [26]. These cells exhibit normal macrophage functions and express properties of activated microglia cells. BV2 cells were cultured in Dulbecco's modified Eagle medium (Gibco, USA) supplemented with 5\% fetal bovine serum (Hyclone). Production of NO was measured by the accumulation of nitrite in the culture medium $24 \mathrm{~h}$ after stimulation with LPS $(0.5 \mu \mathrm{g} / \mathrm{ml})$ or IFN $(20 \mathrm{ng} / \mathrm{ml})$ by the Griess reagent. Intracellular ROS accumulation was measured as in our previous report [25].

\section{Statistical analysis}

All values in the text and figures are presented as the mean \pm SEM Data were analyzed by one-way or two-way analysis of variance (ANOVA) depending on the number of parameters for comparison followed by post-hoc Dunnett's $t$-test for multiple comparisons. Values of $p<0.05$ were considered significant.

\section{Results}

Protective effect of taxifolin against $C I / R$-induced cerebral infarction

The infarct volume induced by $\mathrm{CI} / \mathrm{R}$ injury in this study (around $20 \%$ of the right brain hemisphere) was comparable with that of our previous reports [20, 27]. Taxifolin $(0.1-1.0 \mu \mathrm{g} / \mathrm{kg})$ dosedependently ameliorated CI/R-induced brain infarction by $40-65 \%$ (Figure 1 upper panel, one-way ANOVA, $p<0.05)$. Treatment with both 0.1 and $1.0 \mu \mathrm{g} / \mathrm{kg}$ (i.v.) taxifolin effectively reduced $\mathrm{CI} / \mathrm{R}$-induced brain infarction (Figure 1 upper panel; one-way ANOVA followed by Dunnett's test, $p<0.05, n=10$ for each group). Quercetin $(1.0 \mu \mathrm{g} / \mathrm{kg}$, i.v.), a flavonoid used as a reference drug, also showed a $45 \%$ protective effect against $\mathrm{CI} / \mathrm{R}$-induced brain infarction.

Protective effects of taxifolin against $C I / R$-induced oxidative and nitrosative tissue damage

Lipid peroxidation and protein tyrosine nitrosylation are two markers for oxidative and nitrosative tissue damage in the brain [28, 29]. In this study, CI/Rinduced cerebral lipid peroxidation, as assayed by MDA formation, occurred in a time-dependent manner that peaked at $24 \mathrm{~h}$ as in our previous report [27]. Taxifolin dose-dependently prevented CI/R-induced MDA formation (Figure 1 lower panel, one-way 
ANOVA, $p<0.05, n=10$ for each group). In addition, NS398, a COX-2 inhibitor included as a positive control for its anti-ischemic property [30], significantly suppressed MDA formation.

$\mathrm{CI} / \mathrm{R}$ injury also induced time-dependent nitrosative cerebral damage as evidenced by the increments in immunoreactivity for protein tyrosine nitrosylation (Figure 2a). Treatment with $1.0 \mu \mathrm{g} / \mathrm{kg}$ (i.v.) taxifolin significantly reduced the immunoreactivity for nitrotyrosine at $24 \mathrm{~h}$ (Figure $2 \mathrm{~b}$ ), indicating that taxifolin prevented cerebral nitrosative damage.

\section{Effects of taxifolin on $C I / R$-induced $C O X-2$ and iNOS expression, and leukocyte infiltration}

Many prooxidative enzymes, including COX-2, NOS, NADPH oxidase (NOX), and myeloperoxidase (MPO), are known to participate in the oxidative and nitrosative stress-induced signaling and brain damage in cerebral ischemia [2]. In this study, $\mathrm{CI} / \mathrm{R}$ induced significant upregulation of COX-2 and iNOS on both the protein (Figure 3a) and gene (Figure 3b) levels at $24 \mathrm{~h}$. Treatment with 0.1 and $1.0 \mu \mathrm{g} / \mathrm{kg}$ (i.v.) taxifolin significantly reduced the immunoreactivity of COX-2 and iNOS (Figure 3a), and their gene expressions (Figure $3 \mathrm{~b}$ ) indicating that the upregulation of prooxidative enzymes, especially COX-2 and iNOS, was limited by taxifolin treatment.

Infiltration of leukocytes to CI/R-injured tissue provides predominant sources for MPO activity, another important prooxidative enzyme responsible for oxidative stress in $\mathrm{CI} / \mathrm{R}$-injured brain. We previously reported that enhancement of MPO activity in $\mathrm{CI} / \mathrm{R}$-injured brain closely paralleled cerebral MDA formation in infarct tissue in a time-dependent manner [27]. In this study, CI/R induced-leukocyte infiltration, as measured by MPO activity in the cerebral infarct area, peaked at $24 \mathrm{~h}$, which was comparable to the result of our previous report [27]. MPO activity in the CI/Rinjured only group was 4.2 -fold higher than that in the sham-operated group (Table 1). Treatment with 0.1 and $1.0 \mu \mathrm{g} / \mathrm{kg}$ (i.v.) taxifolin or a COX-2 inhibitor (NS398, $1.0 \mu \mathrm{g} / \mathrm{kg}$, i.v.) all significantly reduced MPO activity in the $\mathrm{CI} / \mathrm{R}$-injured cerebral cortex (Table 1, one-way ANOVA followed by Dunnett's test, $p<0.05, n=6$ for each group) indicating that leukocyte infiltration was inhibited by treatment with taxifolin and NS398.

\section{Effect of taxifolin on ROS and NO production in neutrophils and microglial cells}

During CI/R injury, activation of microglial cells and infiltration of peripheral leukocytes may damage brain tissue by producing enormous amounts of ROS and/or RNS (when superoxide anion combines with NO) [6]. ROS and RNS also signal the transcription of many inflammatoryrelated genes and proteins (e.g., cytokines, adhesion molecules, COX-2, iNOS, etc.) possibly by activation of NF- $\kappa b$ [31-32]. To examine whether taxifolin can prevent ROS or NO production, an in vitro study was performed on oxidative bursts of rat peripheral blood neutrophils and a murine microglial cell line (BV2).

PMA-induced ROS production in rat neutrophils, as assayed by luminol-amplified chemiluminescence at $\sim 25,879 \pm 261 \mathrm{RLU}$, was 208 -fold higher than that of the vehicle control (124 \pm 30 RLU). Pretreatment with taxifolin concentration-dependently inhibited the PMA-induced luminol-amplified chemiluminescence (one-way ANOVA, $p<0.05, n=5$ ) with an $\mathrm{IC}_{50}$ of $\sim 28 \mu \mathrm{M}$ (Table 2). NS-398 (a COX-2 inhibitor), quercetin (an analogue of taxifolin), and apocynin (an inhibitor of NADPH oxidase) [33] used in this test as reference drugs, also significantly inhibited PMA-induced ROS production (Table 2). Ibuprofen, a COX-1 inhibitor, did not significantly inhibit ROS production in rat leukocytes $\left(\mathrm{IC}_{50}>100 \mu \mathrm{M}\right)$. In microglial cells, both LPS and IFN- $\gamma$ enhanced the production of ROS $(\mathrm{FI})$ and $\mathrm{NO}(\mu \mathrm{M})$ to around 3 -fold higher than resting cells (Table 3). Pretreatment with taxifolin $(10 \mu \mathrm{M})$ significantly inhibited the production of ROS and NO (Table 3; one-way ANOVA, $p<0.05, \quad n=5-6)$. Trolox (an anti-oxidant) and L-NAME (an NOS inhibitor) were included to contrast taxifolin's effect, and both significantly antagonized ROS and NO production (Table 3; one-way ANOVA, $p<0.05, n=5-6$ ).

Effect of taxifolin on CI/R-induced ICAM-1 expression in the cerebral cortex and PMA-induced Mac-1 upregulation in rat peripheral neutrophils

Infiltration of peripheral leukocytes to ischemiainjured tissue primarily depends on the upregula- 
(a)

$46 k d$

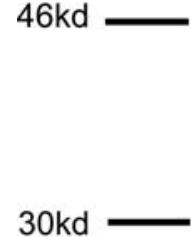

$30 \mathrm{kd}$

$\beta$-actin

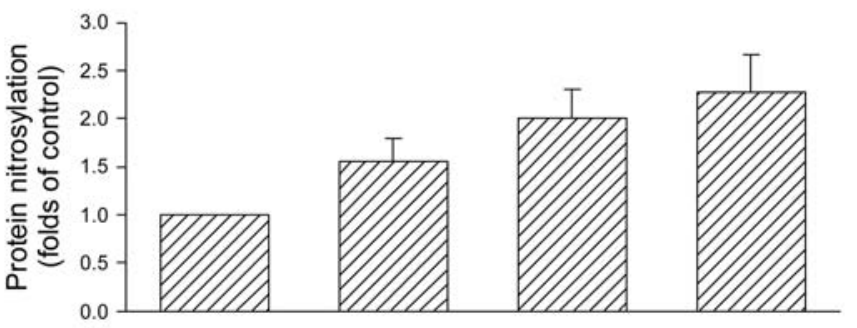

(b)

S

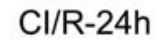

--
--

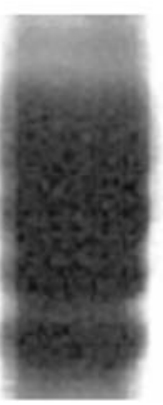

$0.1 \mathrm{~T}$

$46 \mathrm{kd}$

okd
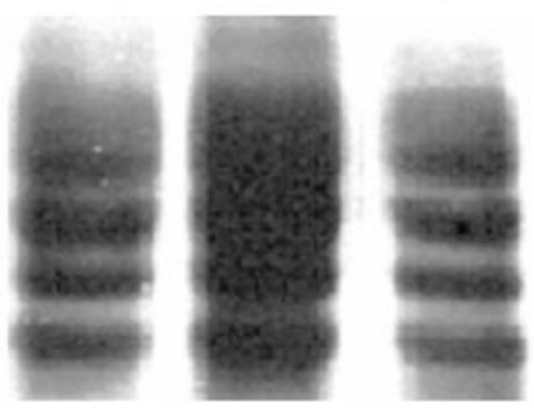

$\mathrm{Cl} / \mathrm{R}+$

$\mathrm{Cl} / \mathrm{R}+$

24
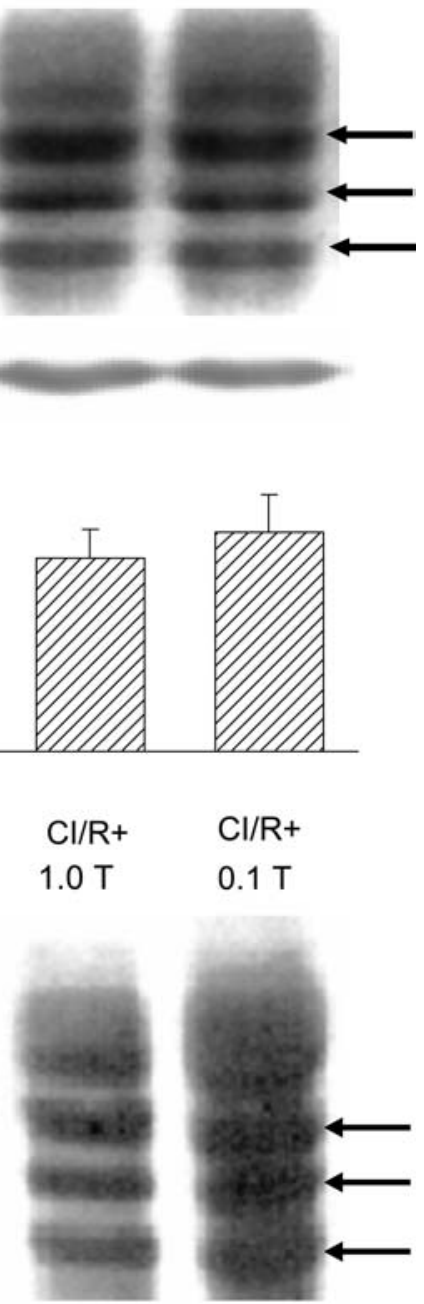

$\beta$-actin

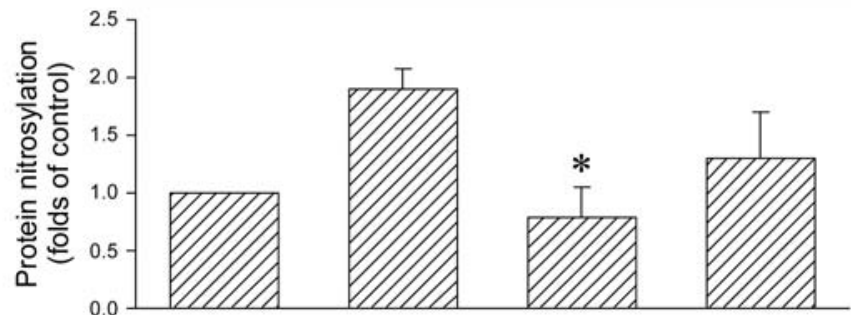

Figure 2. Effect of taxifolin on CI/R-induced protein nitrosylation in the rat cerebral cortex. (a) Time-dependent (0-24 h) analysis of protein nitrosylation after $\mathrm{CI} / \mathrm{R}$ injury. The cerebral cortex was removed for determination of protein nitrosylation by immunoblotting. Three major protein nitrosylation bands as indicated (arrow) were used for the statistical analysis (lower panel). Data were calculated as multiples of the control $(0 \mathrm{~h})$ after normalization to $\beta$-actin, respectively, and are expressed as the mean \pm SEM $(n=5$ for each data point). (b) Formation of protein nitrosylation from sham-operated rats (S) or rats receiving vehicle control $(\mathrm{CI} / \mathrm{R}-24 \mathrm{~h})$ or 0.1 and $1.0 \mu \mathrm{g} / \mathrm{kg}$ (i.v.) taxifolin followed by $\mathrm{CI} / \mathrm{R}$ injury for $24 \mathrm{~h}(\mathrm{CI} / \mathrm{R}+0.1 \mathrm{~T}$ or $\mathrm{CI} / \mathrm{R}+1.0 \mathrm{~T})$. Data were calculated as multiples of the control (sham) after normalization to $\beta$-actin, respectively, and are expressed as the mean $\pm \operatorname{SEM}(n=5$ for each data point). ${ }^{*} p<0.05$ as compared with the $\mathrm{CI} / \mathrm{R}$ only group by one-way ANOVA followed by Dunnett's test. 

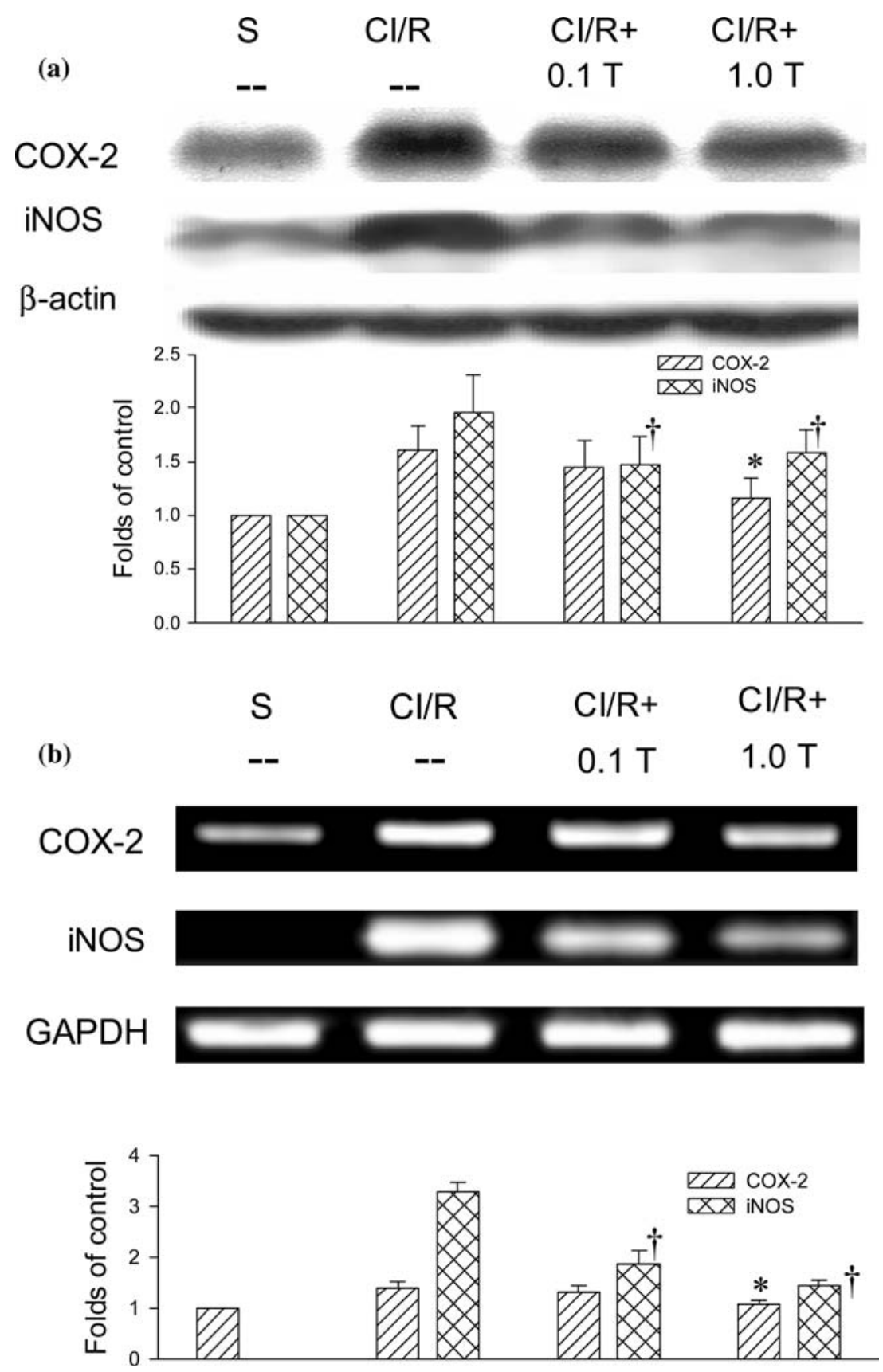

Figure 3. Effect of taxifolin on $\mathrm{CI} / \mathrm{R}$-induced COX-2 and iNOS expression in the rat cerebral cortex. (a) COX-2 and iNOS proteins or (b) genes were determined by immunoblotting or semiquantitative RT-PCR. The cerebral cortex was removed from sham-operated rats $(\mathrm{S})$ or $\mathrm{CI} / \mathrm{R}$-injured rats receiving the vehicle control $(\mathrm{CI} / \mathrm{R})$ or 0.1 or $1.0 \mu \mathrm{g} / \mathrm{kg}$ (i.v.) taxifolin $(\mathrm{CI} / \mathrm{R}+0.1 \mathrm{~T}$ or $\mathrm{CI} / \mathrm{R}+1.0 \mathrm{~T}) . \beta$-actin or the GAPDH gene was included as reference for normalization. The lower panel of each figure shows the statistical results (mean $\pm \mathrm{SEM}, n=5$ ) of the densitometric measurements after normalization to $\beta$-actin or GAPDH. ${ }^{*, \dagger} p<0.05$ as compared with the $\mathrm{CI} / \mathrm{R}$ only group for COX-2 and iNOS, respectively, by one-way ANOVA followed by Dunnett's test.

tion of firm adhesion molecules, especially Mac-1 $(\mathrm{CD} 11 \mathrm{~b} / \mathrm{CD} 18)$ in neutrophils and its counter ligands in endothelial cells, i.e., intercellular adhesion molecule 1 (ICAM-1) [34]. In this study, $\mathrm{CI} / \mathrm{R}$ induced a significant upregulation of ICAM1 in $\mathrm{CI} / \mathrm{R}$-injured cerebral cortex at $24 \mathrm{~h}$ 
Table 1. Decrease in $\mathrm{CI} / \mathrm{R}$-induced leukocyte infiltration (MPO activity) by taxifolin in the rat cerebral cortex $24 \mathrm{~h}$ after middle cerebral arterial occlusion and reperfusion.

\begin{tabular}{ll}
\hline Groups & $\begin{array}{l}\text { MPO activity }(10,000 \\
\left.\times \mathrm{OD}_{460} / \mathrm{mg} \text { protein }\right)\end{array}$ \\
\hline Sham & $112 \pm 25^{*}$ \\
$\mathrm{CI} / \mathrm{R}$ only & $473 \pm 30$ \\
$\mathrm{CI} / \mathrm{R}+\mathrm{TAXI}(\mu \mathrm{g} / \mathrm{kg}$, i.v. $)$ & - \\
0.1 & $260 \pm 36^{*}$ \\
1.0 & $125 \pm 17^{*}$ \\
$\mathrm{CI} / \mathrm{R}+\mathrm{NS}-398$ & $149 \pm 49^{*}$
\end{tabular}

Data are expressed as the mean $\pm \operatorname{SEM}$ ( $n=6$ for each group). ${ }^{*} p<0.05$ as compared with the $\mathrm{CI} / \mathrm{R}$ only group by one-way ANOVA followed by Dunnett's test.

Table 2. Summary of the $\mathrm{IC}_{50}$ and maximum inhibition values for the prevention of ROS production by taxifolin and some reference drugs in rat peripheral leukocytes.

\begin{tabular}{lll}
\hline Drugs & $\begin{array}{l}\mathrm{IC}_{50}(\mu \mathrm{M}) \text { for } \\
\text { ROS production }\end{array}$ & $\begin{array}{l}\text { Maximum } \\
\text { inhibition }(\%)\end{array}$ \\
\hline Taxifolin & $28.3 \pm 3.7$ & $95.4 \pm 0.7$ \\
Quercetin & $30.2 \pm 4.2$ & $92.5 \pm 1.4$ \\
Apocynin & $21.1 \pm 7.5$ & $72.7 \pm 3.64$ \\
Ibuprofen & $>100$ & $10.0 \pm 2.6$ \\
NS-398 & $30.5 \pm 5.1$ & $58.0 \pm 3.6$ \\
\hline
\end{tabular}

Data are expressed as the $50 \%$ inhibitory concentration $\left(\mathrm{IC}_{50}\right)$. Maximum inhibition was determined at $50 \mu \mathrm{M}$ for each drug. Values represent the mean \pm SEM of five experiments performed on different days using cells from different rats.

(Figure 4). Taxifolin treatment $(1.0 \mu \mathrm{g} / \mathrm{kg}$, i.v.) significantly inhibited ICAM-1 protein (Figure 4a) and gene (Figure $4 \mathrm{~b}$ ) expressions in the infarct area. In vitro examination of taxifolin's effect on Mac-1 upregulation in peripheral rat neutrophils revealed that taxifolin concentration-dependently inhibited PMA-induced Mac-1 upregulation (Figure 5, one-way ANOVA, $p<0.05, n=5$ ).

\section{Effect of taxifolin on $C I / R$-induced $N F-\kappa B$ activation}

$\mathrm{NF}-\kappa \mathrm{B}$ has been reported to be a biomarker for oxidative stress associated with ischemic reperfusion injury. Activation of NF- $\kappa \mathrm{B}$ may be the down-stream signaling pathway of ROS or RNS for the transcription of many inflammatoryrelated genes and proteins (e.g., cytokines, adhesion molecules, COX-2, iNOS) [31-32]. In this study, $\mathrm{CI} / \mathrm{R}$ enhanced $\mathrm{NF}-\kappa \mathrm{B}$ activation to
Table 3. Inhibition of ROS (fluorescence intensity) and NO $(\mu \mathrm{M})$ production by taxifolin in murine microglial cells.

\begin{tabular}{llllll}
\hline \multirow{2}{*}{ Inducer } & \multicolumn{2}{c}{ LPS } & & \multicolumn{2}{c}{ IFN- $\gamma$} \\
\cline { 2 - 3 } \cline { 5 - 6 } & ROS & NO & & ROS & NO \\
\hline control (drug free) & $10 \pm 0^{*}$ & 0 & & $10 \pm 0^{*}$ & 0 \\
Inducer alone & $27 \pm 3$ & $27 \pm 3$ & & $33 \pm 3$ & $29 \pm 1$ \\
+ Taxifolin $10 \mu \mathrm{M}$ & $20 \pm 2^{*}$ & $13 \pm 0^{*}$ & & $19 \pm 4^{*}$ & $19 \pm 2^{*}$ \\
+ Trolox $50 \mu \mathrm{M}$ & $10 \pm 1^{*}$ & N.D. & & $15 \pm 1^{*}$ & N.D. \\
+ L-NAME $20 \mu \mathrm{M}$ & N.D. & $19 \pm 1^{*}$ & & N.D. & $17 \pm 0^{*}$ \\
\hline
\end{tabular}

Data are expressed as the mean \pm SEM $(n=5-6$ for each data point). ${ }^{*} p<0.05$ as compared with the inducer $(0.5 \mu \mathrm{g} / \mathrm{ml}$ LPS or $20 \mathrm{ng} / \mathrm{ml}$ IFN- $\gamma$ ) alone by one-way ANOVA followed by Dunnett's test. N.D., data not determined.

around 2.5-fold over that of sham group (Table 4). Treatment with both 0.1 and $1.0 \mu \mathrm{g} / \mathrm{kg}$ (i.v.) taxifolin significantly reduced NF- $\kappa \mathrm{B}$ activation in the CI/R-injured cerebral cortex (Table 4, oneway ANOVA followed by Dunnett's test, $p<0.05$, $n=4$ for each data point) indicating that activation of NF- $\kappa$ B was modulated by taxifolin treatment.

\section{Discussion}

Taxifolin is a potent anti-inflammatory drug against leukocyte activation [17]. Herein we demonstrated for the first time that taxifolin also reduced cerebral ischemic reperfusion $(\mathrm{CI} / \mathrm{R})$ injury. Rats subjected to $\mathrm{CI} / \mathrm{R}$ revealed typical markers of cerebral inflammation and oxidative/ nitrosative injury including infarction (increased TTC-staining), oxidative and nitrosative tissue damage (increased cerebral MDA formation and protein tyrosine nitrosylation), leukocyte infiltration into the infarct area (enhanced MPO activity), upregulation of adhesion molecules (ICAM-1), and induction of prooxidative enzymes (COX-2 and iNOS). These data established a typical pattern of $\mathrm{CI} / \mathrm{R}$ injury that was characterized by protein modifications of oxidative and nitrosative pathways in brain tissue in relation to the activation of inflammatory mediators. Taxifolin treatment showed protective effects in the reduction of $\mathrm{CI} / \mathrm{R}$-induced oxidative and nitrosative tissue damage by blocking inflammation-related events and expression of prooxidative enzymes.

It has been reported that flavonoids structurally related to quercetin exhibit neuroprotective actions against oxidative injuries induced in cor- 
tical cell cultures, but their effects in animal models (in vivo) and the molecular mechanisms of action remain unclear [35]. In this study, we found that both taxifolin (dihydroquercetin) and quercetin exhibited neuroprotective effects against $\mathrm{CI} / \mathrm{R}$ injury in rats, and taxifolin was more potent than quercetin in the prevention of $\mathrm{CI} / \mathrm{R}$-induced brain infarction. Although quercetin has been demonstrated to be better than taxifolin in protecting against oxidative injuries in cortical cell cultures [35], in this study we used taxifolin in the following experiments to further elucidate its mechanisms of action in the amelioration of $\mathrm{CI} / \mathrm{R}$-induced brain injury.

Taxifolin dose-dependently $(0.1$ and $1.0 \mu \mathrm{g} / \mathrm{kg})$ inhibited TTC staining by $40-65 \%$, and almost completely blocked cerebral MDA formation (an oxidative damage marker) indicating that multiple pathological mechanisms more than lipid peroxidation can mediate ischemic stroke-induced cerebral damage which was modulated by taxifolin. Therefore, other mechanisms of action of taxifolin in mediating its anti-stroke effect were further explored and illustrated in this study.

Activation of inducible nitric oxide synthase (iNOS) in microglial cells and infiltration of leukocytes (predominantly neutrophils) provide an important source for $\mathrm{NO}$ and ROS production during CI/R injury [36], although different observations have been reported [37]. The present study together with our previous results [38] confirmed that $\mathrm{CI} / \mathrm{R}$-induced infarction developed along with leukocyte infiltration into the infarct area that also paralleled cerebral lipid peroxidation in the infarct area, indicating that oxidative stress elicited by leukocytes did contribute to the infarction. Taxifolin dose-dependently prevented CI/R-induced leukocyte accumulation (Table 1) and effectively decreased the ROS produced by leukocytes (Table 2), and ROS and NO produced by microglial cells (Table 3 ), revealing that the anti-oxidative effect is responsible for taxifolin's protective effects, and taxifolin could exert its protective effects by modulating inflammatory cells including microglial cells and leukocytes. An inhibitor for COX-2 (NS398), but not COX-1 (ibuprofen), and a direct NADPH oxidase inhibitor (apocynin) both significantly prevented ROS production by neutrophils (Table 2), indicating that direct COX2 and/or NADPH oxidase inhibition may also be potential targets for anti-stroke drug design.
In addition to oxidative stress, nitrosative stress-mediated activation of inflammation mediators is currently being emphasized as an important factor involved in post-traumatic stress disorder, neurodegeneration, and $\mathrm{I} / \mathrm{R}$ injury [3, 39]. Nitrosative stress during the above-mentioned conditions arises primarily from the huge accumulation of NO by over-expression of iNOS or nNOS in the brains of $\mathrm{CI} / \mathrm{R}$-injured animal which form peroxynitrite $\left(\mathrm{ONOO}^{-}\right)$by reaction with the superoxide anion $\left(\mathrm{O}_{2}^{-}\right)$[40]. Peroxynitrite is a tissue-damaging agent that acts through initiation of lipid peroxidation, oxidation of sulfhydryl groups, and nitrosylation of tyrosine-containing molecules. In this study, we found that $\mathrm{CI} / \mathrm{R}$ induced time-dependent protein tyrosine nitrosylation. Upregulation of iNOS but not nNOS (data not shown) in the brain was responsible for the nitrosative brain damage induced by $\mathrm{CI} / \mathrm{R}$. A similar observation was also shown in another' report [41]. Taxifolin treatment significantly prevented protein tyrosine nitrosylation and iNOS expression indicating that iNOS-induced nitrosative stress was diminished by taxifolin.

Inflammatory cascades triggered by $\mathrm{CI} / \mathrm{R}$ injury further amplify tissue damage [4]. For example, leukocytes, macrophages, and active microglial cells are recruited into ischemic tissue where inflammatory mediators are generated by these cells or by neurons and astrocytes. Among these mediators, cyclooxygenase $2(\mathrm{COX}-2)$ has a crucial role in mediating $\mathrm{CI} / \mathrm{R}$ injury. Notably, administration of a COX-2 inhibitor (NS-398) was shown to reduce infarct volume and improve neurological deficits [30]. In this study, we observed that rats pretreated with NS-398 $(1.0 \mu \mathrm{g} / \mathrm{kg}$, i.v. $)$ were protected against $\mathrm{CI} / \mathrm{R}$ induced infarction, cerebral MDA formation, and leukocyte infiltration (MPO activity) with comparable efficacies as those of taxifolin. We also observed that COX-2 was upregulated after $\mathrm{CI} / \mathrm{R}$. Taxifolin significantly reduced COX-2 gene and protein expressions, but whether COX-2 activity was also suppressed by taxifolin awaits further investigation.

Moreover, infiltration of leukocytes (primarily neutrophils) into the infarct areas following $\mathrm{CI} / \mathrm{R}$ began with enhanced firm adhesion of peripheral leukocytes through Mac-1, a beta-2 integrin, to endothelium adhesion molecules (e.g., ICAM-1). Our data demonstrated that $\mathrm{CI} / \mathrm{R}$-induced infarc- 
138

$\begin{array}{lcccc} & \mathrm{S} & \mathrm{Cl} / \mathrm{R} & \mathrm{Cl} / \mathrm{R}+ & \mathrm{Cl} / \mathrm{R}+ \\ \text { (a) } & -- & -- & 1.0 \mathrm{~T} & 0.1 \mathrm{~T}\end{array}$

ICAM-1

$\beta$-actin

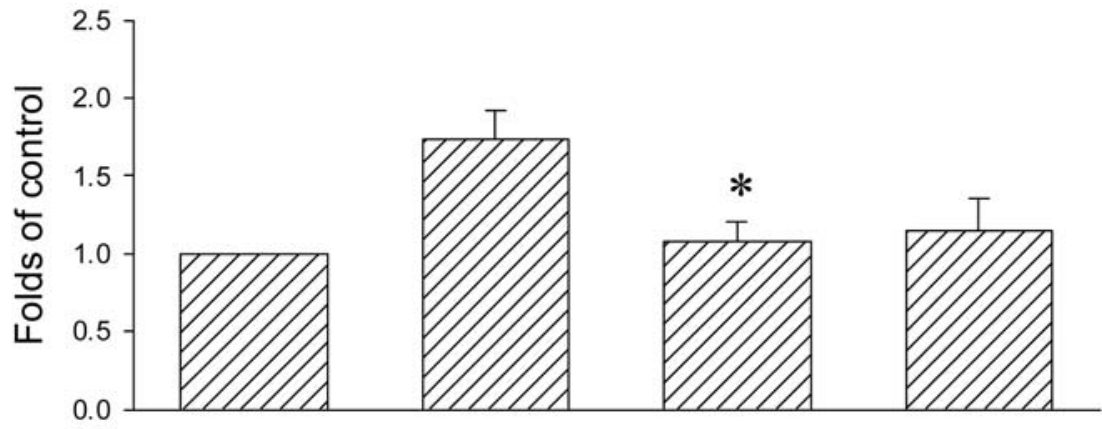

(b) $\quad$-- $\quad$-- $\quad 1.0 \mathrm{~T} \quad 0.1 \mathrm{~T}$

$\mathrm{S} \quad \mathrm{Cl} / \mathrm{R} \quad \mathrm{Cl} / \mathrm{R}+\quad \mathrm{Cl} / \mathrm{R}+$

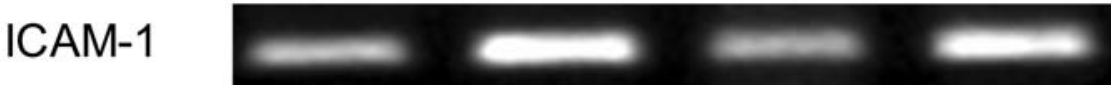

GAPDH

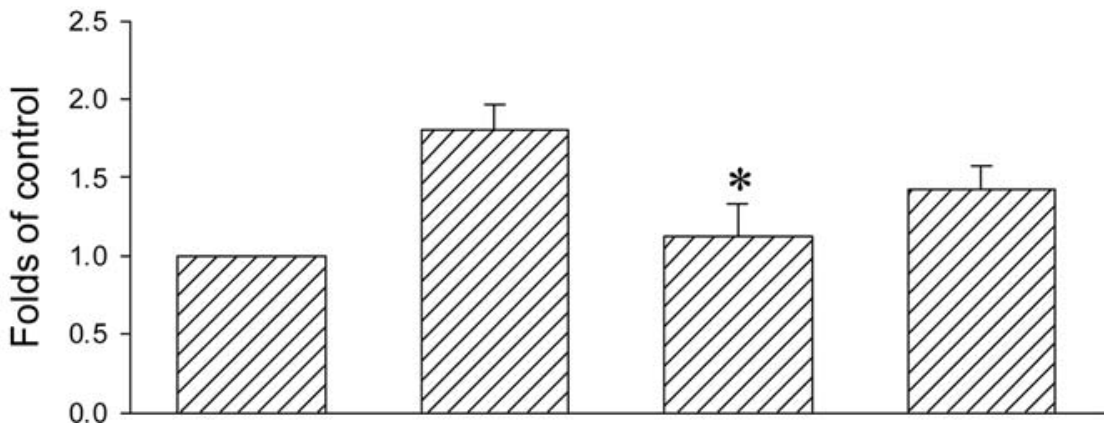

Figure 4. Effect of taxifolin on CI/R-induced ICAM-1 expression in the rat cerebral cortex. (a) ICAM-1 protein and (b) gene were determined by immunoblotting or RT-PCR, respectively. The cerebral cortex was removed from sham-operated rats (S) or CI/Rinjured rats receiving vehicle control $(\mathrm{CI} / \mathrm{R})$ or 0.1 or $1.0 \mu \mathrm{g} / \mathrm{kg}$ taxifolin $(\mathrm{CI} / \mathrm{R}+0.1 \mathrm{~T}$ or $\mathrm{CI} / \mathrm{R}+1.0 \mathrm{~T})$. $\beta$-actin or the GAPDH gene was included as a reference for normalization. The lower panel of each figure shows the statistical results (mean \pm SEM) of the densitometric measurements after normalization. ${ }^{*} p<0.05$ as compared with the $\mathrm{CI} / \mathrm{R}$ only group by one-way ANOVA followed by Dunnett's test. 


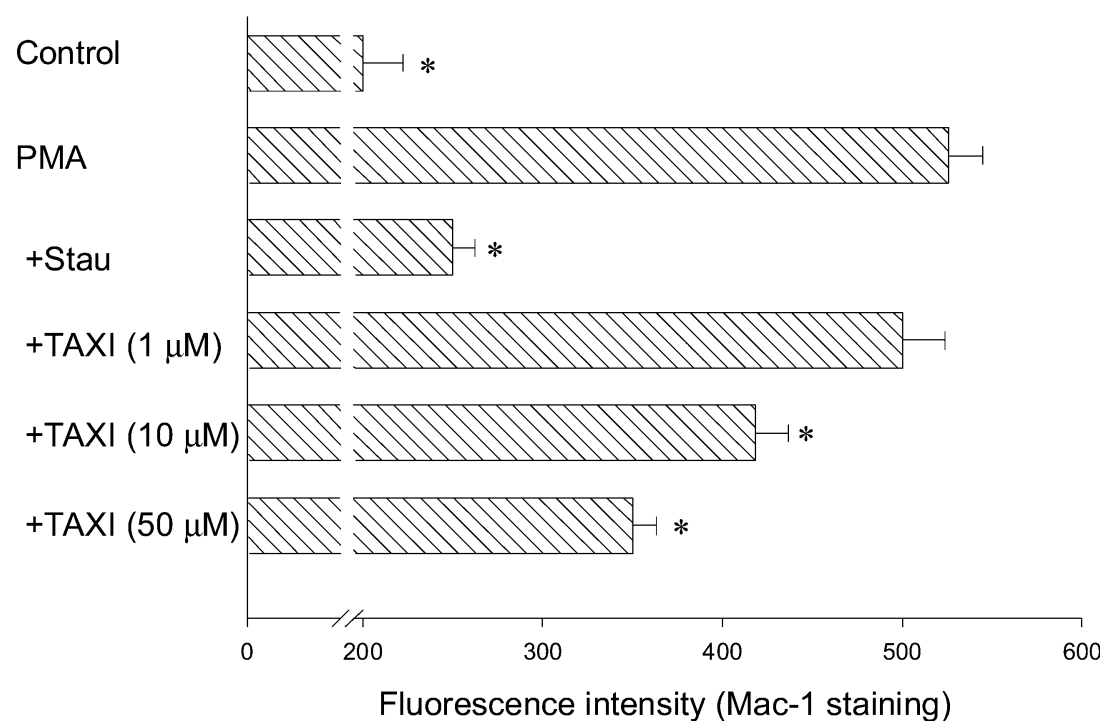

Figure 5. Effect of taxifolin on Mac-1 upregulation in peripheral rat neutrophils. Surface levels of Mac-1 upregulation induced by PMA $(0.2 \mu \mathrm{M})$ were measured by staining with FITC-conjugated anti-rat CD11b and analyzed on a flow cytometer (FACSCalibur $^{\mathrm{TM}}$ ) in the absence or presence of $1-50 \mu \mathrm{M}$ taxifolin (TAXI). Staurosporine (Stau; $20 \mathrm{nM}$ ), a protein kinase $c$ (PKC) inhibitor, was included as a control to block PKC activity. Samples receiving neither PMA nor TAXI were used as the background control (control). Data were represented as the mean channel fluorescence intensity and are expressed as the mean \pm SEM from five independent trials in each group. ${ }^{*} p<0.05$ as compared with PMA group by one-way ANOVA followed by Dunnett's test.

Table 4. Decrease in $\mathrm{CI} / \mathrm{R}$-induced $\mathrm{NF}-\kappa \mathrm{B}$ activation by taxifolin in the rat cerebral cortex $4 \mathrm{~h}$ after middle cerebral arterial occlusion and reperfusion.

\begin{tabular}{ll}
\hline Groups & $\begin{array}{l}\text { NF- } \kappa \text { B activity } \\
\text { (RLU/mg protein) }\end{array}$ \\
\hline Sham & $10,444 \pm 252^{*}$ \\
CI/R only & $24,623 \pm 376$ \\
+ Wild-type competitor & $7,279 \pm 340^{*}$ \\
+ Mutant competitor & $24,712 \pm 325$ \\
CI/R + TAXI $(\mu \mathrm{g} / \mathrm{kg} ;$ i.v. $)$ & - \\
0.1 & $18,264 \pm 366^{*}$ \\
1.0 & $12,012 \pm 178^{*}$ \\
TNF- $\alpha$-stimulated HeLa & $49,490 \pm 185^{*}$ \\
\hline
\end{tabular}

Data are expressed as the mean $\pm \operatorname{SEM}(n=4$ for each data point). ${ }^{*} p<0.05$ as compared with the $\mathrm{CI} / \mathrm{R}$ only group by oneway ANOVA followed by Dunnett's test.

tion developed along with leukocyte infiltration into the infarcted tissue. Expression of ICAM-1, a counter-receptor for Mac-1, was significantly enhanced in the infarct area. Rats treated with taxifolin significantly inhibited ICAM-1 expression. In vitro examination of Mac-1 upregulation in peripheral leukocyte was prevented by taxifolin, possibly via impairment of ROS generation produced by NADPH oxidase through interfering with the p38 MAPK- and/or PKC-dependent signals, and antagonizing the $\mathrm{G}$ protein-mediated calcium influx which in turn inhibited Mac-1dependent neutrophil firm adhesion, a prerequisite step before leukocyte transmigration [17]. Furthermore, TNF- $\alpha$ and IL- $1 \beta$ were reported to upregulate ICAM-1 expression during $\mathrm{CI} / \mathrm{R}$ injury [42-43]. We also observed that both TNF- $\alpha$ and IL-1 $\beta$ genes were up-regulated 6-fold higher than that in sham-operated rats in our $\mathrm{CI} / \mathrm{R}$ model at $24 \mathrm{~h}$, and treatment of taxifolin significantly reduced both genes expressions to 2-3-fold (data not showed). These results may partially account for the suppression of ICAM-1 upregulation by taxifolin. Therefore, the cerebral protective effect of taxifolin paralleled the impediment of leukocyte infiltration into the cerebral foci by reducing adhesion molecule upregulation by $\mathrm{CI} / \mathrm{R}$. These results confirmed that leukocyte activation and infiltration play pivotal roles in mediating $\mathrm{CI} / \mathrm{R}$ injury. Taxifolin, as a potent antioxidant and an inhibitor of leukocyte activation/infiltration, may be a novel $\mathrm{CI} / \mathrm{R}$ injury protective agent.

Furthermore, we found that taxifolin acted not only as an anti-inflammatory and antioxidative agent but also displayed inhibitory effects on the expression of proinflammatory proteins (iNOS and COX-2) and cytokines (IL- $1 \beta$ and TNF- $\alpha$ ), indicating that transcription factor(s) may be 
modulated by taxifolin. Since most of these inflammatory-related proteins are down stream gene products of transcription factor $\mathrm{NF}-\kappa \mathrm{B}$ that was activated during oxidative and/or inflammatory stress, it is reasonable that taxifolin might also modulate the signaling pathways leading to activation of $N F-\kappa \mathrm{B}$. Our data revealed that taxifolin decreased $\mathrm{NF}-\kappa \mathrm{B}$ activation in $\mathrm{CI} / \mathrm{R}$-injured rats, and our unpublished data showed that taxifolin inhibited $\mathrm{NF}-\kappa \mathrm{B}$ transcriptional activation in the transient transfected macrophage cell line with a plasmid containing a triple $\mathrm{NF}-\kappa \mathrm{B}$ binding site in a luciferase reporter gene, indicating that taxifolin suppressed NO or inflammatory-related genes via a NF- $\kappa \mathrm{B}$-dependent mechanism. However, we could not rule out the possibility that suppression of $\mathrm{NF}-\kappa \mathrm{B}$ activation by taxifolin might be a secondary event through its antioxidative effect. More precise mechanism(s) needs further investigations.

In conclusion, our study demonstrated that taxifolin significantly protected rat brain against $\mathrm{CI} / \mathrm{R}$ injury through diminishing cerebral lipid peroxidation (MDA formation) and protein nitrosylation by limiting leukocyte infiltration and upregulation of adhesion molecules (Mac-1 and ICAM-1), and inflammatory-related prooxidative enzymes (iNOS and COX-2) in injured tissue via, at least in part, reducing the activation of $\mathrm{NF}-\kappa \mathrm{B}$. As a potent antioxidative and antinitrosative drug, taxifolin could be beneficial for the prevention and/or amelioration of $\mathrm{CI} / \mathrm{R}$ injury.

\section{Acknowledgements}

This study was supported, in part, by grants from the National Science Council, R.O.C. (NSC-932320-B-077-004), the National Research Institute of Chinese Medicine (NRICM93-DBCMR-09), and Tao-yuan and Hsin-chu General Hospitals, Department of Health, Taiwan, to Y.C. Shen, S. Chang, and W.Y. Wang, respectively.

\section{References}

1. Klijn C.J. and Hankey G.J., Management of acute ischaemic stroke: new guidelines from the American Stroke Association and European Stroke Initiative. Lancet. Neurol. 2: 698-701, 2003.
2. Chan P.H., Reactive oxygen radicals in signaling and damage in the ischemic brain. J. Cereb. Blood F. Met. 21: 2-14, 2001.

3. Madrigal J.L.M., Caso J., Hurtado O., Lizasoain I., Moro M.A., Lorenzo P. and Leza J.C., Brain Oxidative markers in stress: possible new drug targets against neuroinflammation. Curr. Neuropharmacol. 2: 183-189, 2004.

4. Allan S.M. and Rothwell N.J., Cytokines and acute neurodegeneration. Nat. Rev. Neurosci. 2: 734-744, 2001.

5. Leker R.R. and Shohami E., Cerebral ischemia and trauma-different etiologies yet similar mechanisms: neuroprotective opportunities. Brain Res. Rev. 39: 55-73, 2002.

6. Lo E.H., Dalkara T. and Moskowitz M.A., Mechanisms, challenges and opportunities in stroke. Nat. Rev. Neurosci. 4: 399-415, 2003.

7. Liang D., Dawson T.M. and Dawson V.L., What have genetically engineered mice taught us about ischemic injury? Curr. Mol. Med. 4: 207-225, 2004.

8. Vinten-Johansen J., Involvement of neutrophils in the pathogenesis of lethal myocardial reperfusion injury. Cardiovasc. Res. 61: 481-497, 2004.

9. Nurmi A., Lindsberg P.J., Koistinaho M., Zhang W., Juettler E., Karjalainen-Lindsberg M.L., Weih F., Frank N., Schwaninger M. and Koistinaho J., Nuclear factor-kappaB contributes to infarction after permanent focal ischemia. Stroke 35: 987-991, 2004.

10. Taylor J.M. and Crack P.J., Impact of oxidative stress on neuronal survival. Clin. Exp. Pharmacol. Physiol. 31: $397-$ 406, 2004.

11. Zhang W., Potrovita I., Tarabin V., Herrmann O., Beer V., Weih F., Schneider A. and Schwaninger M., Neuronal activation of NF-kappaB contributes to cell death in cerebral ischemia. J. Cereb. Blood F. Met. 25: 30-40, 2005.

12. Middleton E. Jr., Kandaswami C. and Theoharides T.C., The effects of plant flavonoids on mammalian cells: implications for inflammation, heart disease, and cancer. Pharmacol. Rev. 52: 673-751, 2000.

13. Dajas F., Rivera F., Blasina F., Arredondo F., Echeverry C., Lafon L., Morquio A. and Heizen H., Cell culture protection and in vivo neuroprotective capacity of flavonoids. Neurotox. Res. 5: 425-432, 2003.

14. Kostyuk V.A. and Potapovich AI, Antiradical and chelating effects in flavonoid protection against silica-induced cell injury. Arch. Biochem. Biophys. 355: 43-481, 998).

15. Skaper S.D., Fabris M., Ferrari V., Dalle C.M. and Leon A., Quercetin protects cutaneous tissue-associated cell types including sensory neurons from oxidative stress induced by glutathione depletion: cooperative effects of ascorbic acid. Free Radic. Biol. Med. 22: 669-678, 1997.

16. Bito T., Roy S., Sen C.K., Shirakawa T., Gotoh A., Ueda M., Ichihashi M. and Packer L., Flavonoids differentially regulate IFN- $\gamma$-induced ICAM-1 expression in human keratinocytes: molecular mechanisms of action. FEBS Lett. 520: 145$152,2002$.

17. Wang Y.H., Wang W.Y., Liao J.F., Chen C.F., Hou Y.C., Liou K.T., Chou Y.C., Tien J.H. and Shen Y.C., Impairment of NADPH oxidase activity by interfering p38 MAPK and PKC, and antagonism of $\mathrm{G}$ protein-mediated calcium influx account for the prevention of Mac-1 dependent neutrophil firm adhesion by taxifolin. Biochem. Pharmacol. 67: 2251-2262, 2004.

18. Aplin A.E., Howe A., Alahari S.K. and Juliano R.L., Signal transduction and signal modulation by cell adhesion 
receptors: The role of integrins, caldherins, immunoglobulin-cell adhesion molecules, and selectins. Pharmcol. Rev. 50: 197-263, 1998.

19. Shen Y.C., Chiou W.F., Chou Y.C. and Chen C.F., Mechanisms in mediating the anti-inflammatory effects of baicalin and baicalein in human leukocytes. Eur. J. Pharmacol. 465: 171-181, 2003.

20. Liou K.T., Lin S.M., Huang S.S., Chih C.L. and Tsai S.K., Honokiol ameliorates cerebral infarction from ischemiareperfusion injury in rats. Planta Med. 69: 130-134, 2003.

21. Swanson R.A., Morton M.T., Wu T.G., Savalos R.A., Davidson C. and Sharp F.R., A semiautomated method for measuring brain infarct volume. J. Cereb. Blood F. Met. 10: 290-293, 1990.

22. Lin T.N., He Y.Y., Wu G., Khan M. and Hsu C.Y., Effect of brain edema on infarct volume in a focal cerebral ischemia model in rats. Stroke 24: 117-121, 1993.

23. Barone F.C., Hillegass L.M., Price W.J., White R.F., Lee E.V., Feuerstein G.Z., Sarau H.M., Clark R.K. and Griswold D.E., Polymorphonuclear leukocyte infiltration into cerebral focal ischemic tissue: myeloperoxidase activity assay and histologic verification. J. Neurosci. Res. 29: 336-345, 1991.

24. Yavuz O., Turkozkan N., Bilgihan A., Dogulu F. and Aykol S., The effect of 2-chloroadenosine on lipid peroxide level during experimental cerebral ischemia-reperfusion in gerbils. Free Radic. Biol. Med. 22: 337-341, 1997.

25. Shen Y.C., Chen C.F. and Chiou W.F., Suppression of rat neutrophil reactive oxygen species production and adhesion by the diterpenoid lactone andrographolide. Planta Med. 66: 314-317, 2000.

26. Blasi E., Barluzzi R., Bocchini V., Mazzolla R. and Bistoni F., Immortalization of murine microglial cells by a v-raf $/ \mathrm{v}$-myc carrying retrovirus. J. Neuroimmunol. 27: 229-237, 1990.

27. Liou K.T., Shen Y.C., Chen C.F., Tsao C.M. and Tsai S.K., Honokiol protects rat brain from focal cerebral ischemia-reperfusion injury by inhibiting neutrophil infiltration and reactive oxygen species production. Brain Res. 992: 159-166, 2003.

28. Kato N., Yanaka K., Nagase S., Hirayama A. and Nose T., The antioxidant EPC-K1 ameliorates brain injury by inhibiting lipid peroxidation in a rat model of transient focal cerebral ischaemia. Acta Neurochir. (Wien) 145: 489493, 2003.

29. Tanaka K., Shirai T., Nagata E., Dembo T. and Fukuuchi Y., Immunohistochemical detection of nitrotyrosine in postischemic cerebral cortex in gerbil. Neurosci. Lett. 235: 85-88, 1997.

30. Sugimoto K. and Iadecola C., Delayed effect of administration of COX-2 inhibitor in mice with acute cerebral ischemia. Brain Res. 960: 273-276, 2003.

31. Clemens J.A., Cerebral ischemia: gene activation, neuronal injury, and the protective roles of anti-oxidant. Free Radic. Biol. Med. 28: 1526-1531, 2000.
32. Jozsef L. and Filep J.G., Selenium-containing compounds attenuate peroxynitrite-mediated NF- $\kappa \mathrm{B}$ and AP-1 activation and interleukin- 8 gene and protein expression in human leukocytes. Free Radic. Biol. Med. 35: 10181027, 2003.

33. Simons J.M., Hart B.A., IpVai Ching T.R., Van Dijk H. and Labadie R.P., Metabolic activation of natural phenols into selective oxidative burst agonists by activated human neutrophils. Free Radic. Biol. Med. 8: 251-258, 1990.

34. Kobayashi A., Imamura H., Isobe M., Matsuyama Y., Soeda J., Matsunaga K. and Kawasaki S., Mac-1 (CD11b/ $\mathrm{CD} 18$ ) and intercellular adhesion molecule-1 in ischemiareperfusion injury of rat liver. Am. J. Physiol. Gastrointest Liver Physiol. 281: G577-G585, 2001.

35. Dok-Go H., Lee K.H., Kim H.J., Lee E.H., Lee J., Song Y.S., Lee Y.H., Jin C., Lee Y.S. and Cho J., Neuroprotective effects of antioxidative flavonoids, quercetin, (+)-dihydroquercetin and quercetin 3-methyl ether, isolated from Opuntia ficus-indica var. saboten. Brain Res. 965: 130-136, 2003.

36. Lerouet D., Beray-Berthat V., Palmier B., Plotkine M. and Margaill I., Changes in oxidative stress: iNOS activity and neutrophil infiltration in severe transient focal cerebral ischemia in rats. Brain Res. 958: 166-175, 2002.

37. Beray-Berthat V., Palmier B., Plotkine M. and Margaill I., Neutrophils do not contribute to infarction, oxidative stress, and NO synthase activity in severe brain ischemia. Exp. Neurol. 182: 446-454, 2003.

38. Liou K.T., Shen Y.C., Chen C.F., Tsao C.M. and Tsai S.K., The anti-inflammatory effect of honokiol on neutrophils: mechanisms in the inhibition of reactive oxygen species production. Eur. J. Pharmacol. 475: 1927, 2003.

39. Bossy-Wetzel E., Schwarzenbacher R. and Lipton S.A., Molecular pathways to neurodegeneration. Nat. Med. 10: S2-S9, 2004.

40. Sugawara T. and Chan P.H., Reactive oxygen radicals and pathogenesis of neuronal death after cerebral ischaemia. Antioxidant Redox Signaling 5: 597-607, 2003.

41. 41 Hirabayashi H., Takizawa S., Fukuyama N., Nakazawa H. and Shinohara Y., Nitrotyrosine generation via inducible nitric oxide synthase in vascular wall in focal ischemiareperfusion. Brain Res. 852: 319-325, 2000.

42. 42 Yang G.Y., Gong C., Qin Z., Ye W., Mao Y. and Bertz A.L., Inhibition of TNF $\alpha$ attenuates infarct volume and ICAM-1 expression in ischemic mouse brain. Neuroreport 9: 2131-2134, 1998.

43. Yang G.Y., Schielke G.P., Gong C., Mao Y., Ge H.L., Liu X.H. and Betz A.L., Expression of tumor necrosis factor-alpha and intercellular adhesion molecule-1 after focal cerebral ischemia in interleukin-lbeta converting enzyme deficient mice. J. Cereb. Blood F. Metab. 19: 1109-1117, 1999. 